\title{
Characterization of surface proteins of Cronobacter muytjensii using monoclonal antibodies and MALDI-TOF Mass spectrometry
}

\author{
Ziad W Jaradat ${ }^{*}$, Abrar M Rashdan', Qotaiba O Ababneh ${ }^{1,2}$, Saied A Jaradat ${ }^{1,3}$ and Arun K Bhunia ${ }^{4}$
}

\begin{abstract}
Background: Cronobacter spp. is a newly emerging pathogen that causes meningitis in infants and other diseases in elderly and immunocompromised individuals. This study was undertaken to investigate surface antigenic determinants in Cronobacter spp. using monoclonal antibodies (MAbs) and MALDI-TOF Mass spectrometry.

Results: Spleenocytes from mice that were immunized with heat-killed $\left(20 \mathrm{~min}, 80^{\circ} \mathrm{C}\right)$ Cronobacter cells were fused with SP2 myeloma cells. Five desirable MAbs (A1, B5, 2C2, C5 and A4) were selected. MAbs A1, B5, 2C2 and C5 were of IgG2a isotype while A4 was an IgM. Specificity of the MAbs was determined by using immunoblotting with outer membrane protein preparations (OMPs) extracted from 12 Cronobacter and 6 non-Cronobacter bacteria. All MAbs recognized proteins with molecular weight ranging between 36 and $49 \mathrm{kDa}$ except for one isolate (44) in which no OMPs were detected. In addition, MAbs recognized two bands (38-41 kDa) in four of the nonCronobacter bacteria. Most of the proteins recognized by the MAbs were identified by MALDI-TOF peptide sequencing and appeared to be heterogeneous with the identities of some of them are still unknown. All MAbs recognized the same epitope as determined by an additive Index ELISA with their epitopes appeared to be conformational rather than sequential. Further, none of the MAbs recognized purified LPS from Cronobacter spp. Specificity of the MAbs toward OMPs was further confirmed by transmission electron microscopy.

Conclusions: Results obtained in this study highlight the immunological cross-reactivity among Cronobacter OMPs and their Enterobacteriaceae counterparts. Nevertheless, the identity of the identified proteins appeared to be different as inferred from the MALDI-TOF sequencing and identification.
\end{abstract}

\section{Background}

Cronobacter spp. (formerly Enterobacter sakazakii) is a non-spore forming, motile, facultative anaerobic Gramnegative bacillus and belongs to family Enterobacteriaceae $[1,2]$. Initially isolates of Cronobacter spp. (Cronobacter) were identified as yellow pigment producing Enterobacter cloacae. Later, Farmer et al., [3] reclassified them as a new species and were given the name sakazakii based on DNA-DNA homology, antibiotic susceptibility patterns and certain unique biochemical characteristics such as catalase production, the absence of oxidase and the production of yellow pigment in all tested strains.

\footnotetext{
* Correspondence: jaradatz@just.edu.jo

'Department of Biotechnology and Genetic Engineering, P. O Box 3030,

Jordan University of Science and Technology, Irbid 22110, Jordan

Full list of author information is available at the end of the article
}

More recent studies utilizing full length 16S rRNA gene sequencing, ribotyping, fluorescent-amplified fragment length polymorphism and DNA-DNA hybridization have demonstrated that Cronobacter is a heterogenic genus exhibiting a high degree of genetic and phenotypic diversity among species and comprises six species: C. muytjensii, C. sakazakii, C. malonaticus, C. turicensis, C. dublinensis and C. genomospecies I [4-7]. Cronobacter is considered an emerging pathogen; though, little is known about its virulence properties and antigenic determinants [8]. Recently, several studies have reported the involvement of an outer membrane protein (OMP), OmpA, in pathogenesis of C. sakazakii; however, nothing is known about its antigenicity. Besides, little is known about OMPs from other Cronobacter species [8-10]. In contrast, the virulence and antigenic properties of OMPs of closely related Enterobacter 
species including E. aerogenes [11] and E. cloacae $[12,13]$ were studied well.

Prematurely born infants with low birth weights and infants in neonatal intensive care units are highly susceptible to Cronobacter infections with the pathogen being transmitted primarily from contaminated environments to the infant formula during the preparation [14-20]. In rare cases, nosocomial infections can happen in adults especially in immunocompromised ones [21]. In 2004, a joint FDA/WHO workshop raised an alert concerning the presence of Cronobacter in powdered infant formula (PIF) and recommended applying higher microbiological standards during its manufacturing [22]. This warning culminated into increased research efforts to study Cronobacter including the development of improved isolation and identification methods, and understanding of the growth and survival characteristics.

Antibodies are the most frequently used tools to study bacterial antigenic determinants; however, little is known about the production of monoclonal antibodies that recognize Cronobacter antigenic determinants. In this paper we describe the production and characterization of 5 MAbs that recognize outer membrane proteins of $\mathrm{Cro}$ nobacter. In addition, antigenic properties, identification, distribution and cell surface localization of the MAbsrecognized OMPs were examined using electron microscopy and MALDI-TOF spectrometry. To our knowledge, this is the first report on using monoclonal antibodies to study the surface antigens of this pathogen.

\section{Methods \\ Materials}

Alkaline phosphatase-conjugated goat anti-mouse immunoglobulin, complete Freund's adjuvant, incomplete Freund's adjuvant, sarkosyl, DMSO, pancreatic RNase and DNase and a mouse subisotyping kit were from Sigma-Aldrich, USA. Gold-conjugated $(18 \mathrm{~nm})$ antimouse IgG was obtained from Jackson Immunochemicals, USA. Polyethelyene glycol 4000 was from Fluka, USA. Micro test plates, tissue culture plates and flasks were from Griener, Germany. Coommassie Brilliant blue G-250 was from BDH chemicals, Ireland and BSA was from Biobasic, Canada; Proteinase $\mathrm{K}$ was from Promega, USA. Goat anti-mouse-conjugated to horse radish peroxidase (HRP) was from Santa Cruz, USA. Penicillin, streptomycin and amphotercin B were from PAA Laboratories $\mathrm{GMBH}$, Austria. Recovery cell culture freezing media was from Gibco, USA. Myeloma SP2 cells were a gift from Dr. Khalid Qaoud, Yarmouk University, Jordan. All other chemicals and reagents were of analytical grade.

\section{Bacteria and growth conditions}

Stock cultures were maintained through out this study on Trypticase Soy Agar (TSA) (Oxoid, UK) or nutrient agar plates (HiMedia, India) at $4^{\circ} \mathrm{C}$ until use. The type strain C. muytjensii ATCC 51329 was grown overnight at $37^{\circ} \mathrm{C}$ in nutrient broth (NB) (HiMedia). Cells were harvested by centrifugation $(5,000 \times \mathrm{g}, 10 \mathrm{~min})$, washed twice with $0.1 \mathrm{M} \mathrm{PBS}(\mathrm{pH} 7.2)$ and adjusted to $10^{8} \mathrm{CFU} \mathrm{ml}{ }^{-1}$ using McFarland standard. Bacterial cells were heated at $80^{\circ} \mathrm{C}$ for $20 \mathrm{~min}$ in a water bath and were subsequently used for immunization of mice and screening of hybridoma cells for MAbs production using ELISA. Several Cronobacter strains used in the study were isolated from Jordan (Table 1). These isolates were identified and characterized by several traditional and molecular methods [19]. The 16S rRNA sequences of the isolates were deposited in the GenBank (MD, USA) (Table 1), while the isolates were deposited in the Egyptian Microbial Culture Collection (Ain Shams University, Cairo, Egypt).

\section{Lipopolysaccharide (LPS) extraction and antigen preparation}

LPS was prepared following the method described by Jaradat and Zawistowski [23], with minor modifications. Briefly, C. muytjensii ATCC 51329 cells were harvested from an overnight culture by centrifugation $(5,000 \times \mathrm{g}$, $10 \mathrm{~min}$ ) and resuspended in $50 \mathrm{ml}$ of $50 \mathrm{mM}$ sodium phosphate buffer, pH 7.0. The cells were sonicated 5 times for $45 \mathrm{~s}$ intervals at 300 Watts (Branson Sonifier). The sonicated suspension was incubated with pancreatic RNase and DNase $\left(0.1 \mu \mathrm{g} \mathrm{ml}^{-1}\right)$ in $20 \mathrm{mM} \mathrm{MgCl}_{2}$ at $37^{\circ} \mathrm{C}$ for $10 \mathrm{~min}$, followed by $10 \mathrm{~min}$ at $60^{\circ} \mathrm{C}$ and then mixed with an equal volume of preheated $90 \%$ phenol. Following incubation $\left(70^{\circ} \mathrm{C}\right.$ for $\left.15 \mathrm{~min}\right)$ with occasional mixing, the mixture was centrifuged $(18,000 \times \mathrm{g}, 1 \mathrm{~h})$ and the resulting aqueous layer was collected and dialyzed using dialysis tubing of 6,000-8,000 MW cutoff at room temperature against several changes of distilled water until no detectable phenol odor remained. The dialysate was treated with $20 \mu \mathrm{g} / \mathrm{ml}$ of Proteinase $\mathrm{K}$ in $0.1 \mathrm{M}$ Tris- $\mathrm{HCl}$ (pH 8.0) at $60^{\circ} \mathrm{C}$ for $1 \mathrm{~h}$ followed by overnight incubation at $37^{\circ} \mathrm{C}$. The samples were then lyophilized and stored at $-20^{\circ} \mathrm{C}$ until used. For antigen preparation, the extracted LPS from Cronobacter was mixed (1:1) with $30 \%(\mathrm{w} / \mathrm{v})$ polyacrylamide solution; ammonium persulfate $(50 \mu \mathrm{l})$ and TEMED $(10 \mu \mathrm{l})$ were added to the mixture to obtain a $15 \%$ polyacrylamide gel $(\mathrm{v} / \mathrm{v})$ [24]. The gel-containing LPS was frozen in liquid nitrogen and ground with a pestle and mortar into a fine powder. The powder was dissolved in $10 \mathrm{ml} \mathrm{PBS} \mathrm{(0.1} \mathrm{M,} \mathrm{pH} \mathrm{7.0)} \mathrm{and} \mathrm{immediately}$ used for immunization [25].

\section{Outer membrane protein extraction}

OMPs were extracted using the sarkosyl-based method described by Davies et al., [26]. Briefly, Cronobacter cells were harvested from overnight cultures by centrifugation, and then treated with $0.1 \mu \mathrm{g}$ of bovine RNase and DNase 
Table 1 Cronobacter and Non-Cronobacter strains used in this study

\begin{tabular}{|c|c|c|c|c|}
\hline Isolate \# & Isolate identity & Source & Isolate ID & GenBank ID based on 16S rRNA sequence \\
\hline- & C. muytjensii & - & ATCC 51329 & - \\
\hline $\mathrm{C} 4$ & C. sakazakii & Clinical & - & \\
\hline C6 & C. sakazakii & Clinical & CDC 407-77 & - \\
\hline $\mathrm{C} 13$ & C. sakazakii & Clinical & ATTC 29004 & - \\
\hline Jor* 44 & C. sakazakii & Food & EMCC 1904 & FJ906902 \\
\hline Jor* 93 & C. sakazakii & Food & EMCC1905 & FJ906906 \\
\hline Jor* 112 & C. muytjensii & Food & EMCC1906 & FJ906909 \\
\hline Jor* $146_{A}$ & C. sakazakii & Food & EMCC1907 & FJ906897 \\
\hline Jor* $146_{B}$ & C. sakazakii & Food & EMCC1908 & FJ906910 \\
\hline Jor* 149 & C. muytjensii & Food & EMCC1909 & FJ906912 \\
\hline Jor* $160_{A}$ & C. sakazakii & Environment & EMCC1910 & FJ906914 \\
\hline Jor* 170 & C. turicensis & Food & EMCC1912 & FJ906916 \\
\hline
\end{tabular}

None-Cronobacter

$\begin{array}{lll}\text { C. freundii } & - & \text { ATCC } 43864 \\ \text { E. coli } & - & \text { ATCC } 35218 \\ \text { L. ivanovii } & - & \text { ATCC } 19119 \\ \text { P aeruginosa } & - & \text { ATCC } 27833 \\ \text { S. enterica Choleraesuis } & - & \text { CIP } 104220 \\ \text { S. sonnei } & - & \text { ATCC } 9290\end{array}$

Jor*: Strains were isolated from food and environmental samples collected in Jordan and were deposited in the Egyptian Microbial Culture Collection (EMCC; Ain Shams University, Cairo, Egypt) and their 16S rRNA sequences were deposited in the GenBank. C: clinical samples isolated from patients obtained from CDC (Atlanta, GA, USA) and were a gift from Dr. Ben Davies Tall from U.S. FDA. All the other isolates were obtained from the American Type Culture Collection (ATCC) except for Salmonella which obtained from the Collection of Institute Pasteur (CIP) and S. sonnei which was a local strain.

in $20 \mathrm{mM} \mathrm{MgCl}$ for $10 \mathrm{~min}$ at $37^{\circ} \mathrm{C}$. Next, the cells were sonicated for $10 \mathrm{~min}$ in $45 \mathrm{sec}$ intervals at 300 watts on crushed ice and were centrifuged $(5,000 \times \mathrm{g}$ for $30 \mathrm{~min}$ at $\left.4^{\circ} \mathrm{C}\right)$. The supernatant was collected and re-centrifuged $\left(29,000 \times \mathrm{g}\right.$ for $2 \mathrm{~h}$ at $\left.4^{\circ} \mathrm{C}\right)$. The resulting pellet was treated with $10 \mathrm{ml}$ of $2 \%(\mathrm{w} / \mathrm{v})$ sarkosyl for $30 \mathrm{~min}$ at room temperature. The mixture was centrifuged $(29,000 \times \mathrm{g}$ for 2 h). The resulting pellet was washed with $10 \mathrm{ml}$ of $20 \mathrm{mM}$ Tris- $\mathrm{HCl}(\mathrm{pH} 7.7)$ containing $2 \%(\mathrm{w} / \mathrm{v}) \mathrm{SDS}$ and re-centrifuged $\left(29,000 \times \mathrm{g}\right.$ for $2 \mathrm{~h}$ at $\left.4^{\circ} \mathrm{C}\right)$. The final pellet, which contained OMPs, was resuspended in distilled water, aliquoted and stored at $-20^{\circ} \mathrm{C}$ for further use.

\section{Production of monoclonal antibodies against Cronobacter spp}

Female Balb/c mice (6 to 8 weeks old) were initially immunized intraperitoneally with $200 \mu \mathrm{l}\left(10^{8} \mathrm{CFU} \mathrm{ml}^{-1}\right)$ of heat-killed bacterial suspension (C. muytjensii ATCC 51329) mixed with complete Freund adjuvant at a 1:1 ratio. Subsequently, 4 booster doses were administrated at weekly intervals using the same amount of immunogen but prepared with incomplete Freund adjuvant. Simultaneously, female Balb/c mice (6 to 8 weeks old) were immunized intraperitoneally with $200 \mu$ l of polyacrylamide-LPS preparation in PBS for at least 8 wks at weekly intervals. Myeloma SP2 cells were maintained in RPMI media supplemented with $10 \%$ Fetal Calf Serum (FCS), $20 \mathrm{U}$ of penicillin, $20 \mathrm{U}$ streptomycin and $2.5 \mu \mathrm{g}$ $\mathrm{ml}^{-1}$ amphotercin B. At the day of fusion, the actively grown myeloma culture was washed twice using serumfree media (SFM) and adjusted to the desired concentration. The fusion was performed according to the method described by Liddell and Cryer [27] using 40\% $(\mathrm{w} / \mathrm{v})$ polyethylene glycol 4000 as the fusing agent in sterile SFM adjusted to $\mathrm{pH}$ 7.4. Spleen cells harvested from immunized mice and myeloma cells were fused at a ratio of 8:1. Two weeks later, hybridomas were screened for the production of MAbs by ELISA using heat killed Cronobacter and non-Cronobacter cells. Hybridomas reacting specifically with Cronobacter were expanded and cloned at least three times by limiting dilution. Positive clones were frozen in recovery cell culture freezing media ${ }^{\circledR}$ or FCS supplemented with $4 \%(\mathrm{v} /$ v) DMSO and stored at $-80^{\circ} \mathrm{C}$ overnight before being transferred to liquid nitrogen. The positive clones were propagated either in tissue culture or by ascitic fluid using the procedure of Harlow and Lane [28]. Isotypes of purified monoclonal antibodies from ascites or spent medium were determined using the mouse type subisotyping kit according to the manufacturer's instructions. 


\section{Immunochemical Methods}

\section{Elisa}

Screening of antisera spent medium and ascites for the presence of antibodies against Cronobacter was performed by an indirect non-competitive ELISA. Flat-bottom 96 well plates were coated with $0.1 \mathrm{ml}$ of $\left(10^{8}\right.$ heatkilled cells $\mathrm{ml}^{-1}$ ) of whole cell antigen diluted in $0.05 \mathrm{M}$ carbonate buffer ( $\mathrm{pH} 9.6)$ overnight at $4{ }^{\circ} \mathrm{C}$. Alkaline phosphatase-conjugate goat anti-mouse immunoglobulin and p-nitrophenyl phosphate were used as secondary antibodies and substrate, respectively.

\section{Additive index elisa}

Additive index ELISA was performed on paired MAbs as described by Friguet et al., [29]. An additive index for each pair of MAbs was calculated according to the formula $\left\{\left[2 A_{1+2} /\left(A_{1}+A_{2}\right)\right]-1\right\} \times 100$, where $A_{1}, A_{2}$, and $A_{1}$ +2 are absorbance values with antibody 1 alone, antibody 2 alone, and the two antibodies together, respectively.

\section{Gel electrophoresis}

Profiles of Cronobacter OMPs were examined using SDS-PAGE following the method described by Laemmli [30]. The runs were performed in 4\% stacking and $12.5 \%$ separating gels. Equal concentrations of Cronobacter OMPs $\left(20 \mu \mathrm{g}\right.$ well $\left.{ }^{-1}\right)$ were mixed with sample buffer at a ratio of $1: 5$, boiled for $5 \mathrm{~min}$ and loaded (approx. $20 \mu \mathrm{l} /$ lane). Gels were either stained with $1 \%$ (w/v) Coommassie Brilliant Blue G-250 or used for immunoblotting. Likewise, LPS preparations from Cronobacter were examined using Deoxycholate-polyacrylamide gel electrophoresis (DOC-PAGE) following the method described by Reuhs et al., [31]. Briefly, the runs were performed using $4 \%(\mathrm{v} / \mathrm{v})$ stacking and $12.5 \%(\mathrm{v} / \mathrm{v})$ separating gels. Equal concentrations of Cronobacter LPS $\left(5 \mu \mathrm{g} \mathrm{well}^{-1}\right)$ were mixed with sample buffer [ $2 \mathrm{ml}$ of $22.7 \%(\mathrm{w} / \mathrm{v})$ Tris-base solution; $1 \mathrm{ml}$ of $50 \%(\mathrm{v} / \mathrm{v})$ glycerol; $1 \mathrm{ml}$ of $1 \%(\mathrm{w} / \mathrm{v})$ bromophenol blue and $6 \mathrm{ml}$ distilled water] at a ratio of 1:5. The gels were pre-run in DOC-electrophoresis buffer (Tris-base, 4.5 g; glycine, 21.7 g; 2.5 g sodium deoxycholate, $\mathrm{pH}$ adjusted to 8.3 and volume adjusted to 1 liter) for $10 \mathrm{~min}$ at 80 volts before loading the samples. Samples were run in the same buffer at 80 and 120 volts for the stacking and separating gels, respectively. Upon completion, gels were either stained using the PageSilver ${ }^{\mathrm{TM}}$ silver staining kit (Fermentas) or were used for immunoblotting. Band sizes for both gels and blots were estimated using the BioRad Quantity One 1-D Analysis Software.

\section{Immunoblotting}

Immediately after completing the electrophoresis run, OMPs and LPS were transferred to nitrocellulose (NC) membranes according to Harlow and Lane [28] with some modifications. Gels and NC membranes were soaked in Tris-glycine transfer buffer $(10 \%$ [v/v] methanol, $24 \mathrm{mM}$ Tris base, $194 \mathrm{mM}$ glycine) for $15 \mathrm{~min}$.
Separated OMPs and LPSs were transferred onto NC using a mini-transblot cell (Bio-Rad). The membranes were blocked with $3 \%(\mathrm{w} / \mathrm{v})$ BSA in Tris Buffered Saline (TBS) containing Tween $20(0.05 \% \mathrm{v} / \mathrm{v})$. NC membranes were then incubated with affinity purified MAbs $(2 \mu \mathrm{g}$ $\mathrm{ml}^{-1}$ ) diluted in $0.15 \mathrm{M}$ TBS buffer containing $1 \%(\mathrm{w} / \mathrm{v})$ BSA with gentle shaking for $1 \mathrm{~h}$. Membranes were then developed with goat anti-mouse-HRP in 0.15 M TBS buffer containing $1 \%(\mathrm{w} / \mathrm{v})$ BSA and a diaminobenzidine (DAB) substrate solution. Color development was stopped by rinsing the membranes with distilled water.

\section{Protein sequencing and identification}

Extracted OMPs were separated on SDS-PAGE gels and probed with anti-OMP monoclonal antibodies. Immunoblot-positive bands were cut with sterile sharp scalpel and immersed in $1 \%$ acetic acid solution. Protein sequencing was performed using the MALDI-TOF technology at the Proteomics and Mass Spectrometry Facility at Purdue University (West Lafayette, Indiana, USA).

\section{Dot blot assay}

Dot blotting was performed as described by Jaradat and Zawistowski [23]. One microliter of heat-killed Cronobacter whole-cell suspension $\left(10^{8}\right.$ cells $\left.\mathrm{ml}^{-1}\right)$ was spotted on the NC membranes, allowed to air dry for $30 \mathrm{~min}$ and incubated in $5 \%(\mathrm{w} / \mathrm{v}) \mathrm{NaOH}$ or in $38 \%(\mathrm{v} / \mathrm{v}) \mathrm{HCl}$ for $10 \mathrm{~s}$ or left untreated. Immunoblotting was performed as described above.

\section{Immunoelectron microscopy}

Immunolabeling was performed essentially as described by Jaradat and Zawistowski [23] with modifications. Briefly, $5 \mu \mathrm{l}$ of bacterial suspension in distilled water $(5$ $\times 10^{8} \mathrm{CFU} \mathrm{ml}{ }^{-1}$ ) were placed on formvar-coated copper grids. After air-drying for $2 \mathrm{~h}$ at room temperature, the grids were blocked with PBS containing 3\% (w/v) BSA for $30 \mathrm{~min}$ at $37^{\circ} \mathrm{C}$. To expose antigens on bacteria, grids were incubated with $0.1 \mathrm{M} \mathrm{NaOH}$ or $0.1 \mathrm{M} \mathrm{HCl}$ for $2 \mathrm{~h}$, washed with water and incubated with purified MAb solution at $37^{\circ} \mathrm{C}$. Grids were then incubated with colloidal gold (18 nm)-conjugate anti-mouse IgG diluted at 1:50 in dilution buffer $(0.02 \mathrm{M}$ Tris, $150 \mathrm{mM} \mathrm{NaCl}$, $0.1 \%[\mathrm{w} / \mathrm{v}] \mathrm{BSA}, 0.005 \%[\mathrm{v} / \mathrm{v}]$ Tween $20,0.4 \%[\mathrm{w} / \mathrm{v}$ ] gelatin [ $\mathrm{pH} 9])$ for $20 \mathrm{~h}$ at room temperature. Grids were washed 6 times with water and viewed with a Zeiss Transmission Electron Microscope at various magnifications.

\section{Animal use}

Animals used for immunization and production of monoclonal antibodies were cared for according to the Animal Care and Use Committee (ACUC), Jordan University of Science and Technology.

\section{Results}

Two approaches were attempted to produce monoclonal antibodies specific to Cronobacter spp.: one group of 
mice was immunized with heat-killed $C$. muytjensi ATCC 51329, while the other group was immunized with LPS purified from C. muytjensii ATCC 51329. Repeated immunization with the LPS produced a good antibody response as judged from both ELISA and immunoblotting results using antisera from LPS-immunized mice which revealed the characteristic ladder pattern of LPS (Figure 1). However, none of the two immunization protocols resulted in a stable hybridoma producing anti-LPS antibodies. Nevertheless, mice immunized with heat-killed cells responded well yielding a high titer after 5 injections. Consequently, mice from this group were sacrificed and two fusions were performed yielding over 500 hybridomas of which approximately 180 clones were positive upon initial screening and were cloned 3 times by limiting dilution [32-34]. Of these, only 5 stable hybridomas secreted antibodies against Cronobacter spp. Four of the hybridomas were of IgG type (A1, B5, 2C2 and C5), while the last hybridoma (A4) was of the IgM class. The avidity of the MAbs to their epitopes was determined by ELISA. The titration curve for all protein G-column purified MAbs, except for A4, revealed that MAb-2C2 had the highest avidity followed by $\mathrm{C} 5, \mathrm{~B} 5$ and A1 having the lowest. MAb A4, an IgM, was not tested as it was not purified by Protein G column affinity chromatography.

\section{Specificity of the monoclonal antibodies}

The specificity of the MAbs was determined by noncompetitive ELISA with various heat- killed bacteria belonging to Cronobacter and non-Cronobacter spp. In general, all MAbs reacted with both Cronobacter and non-Cronobacter spp. with higher titers generally obtained for Cronobacter spp. (Titer of 3200 Cronobacter versus 400 for some non-Cronobacter). Nevertheless, some non-Cronobacter spp. also gave titers comparable to those obtained for Cronobacter (Titer 3200). The binding affinities varied among the four MAbs with MAbs 2C2 and C5 gave titers of 3200 against almost all the heat-killed Cronobacter strains tested, whereas MAbs A1 and B5 had titers ranging between 800 to more than 6400 .

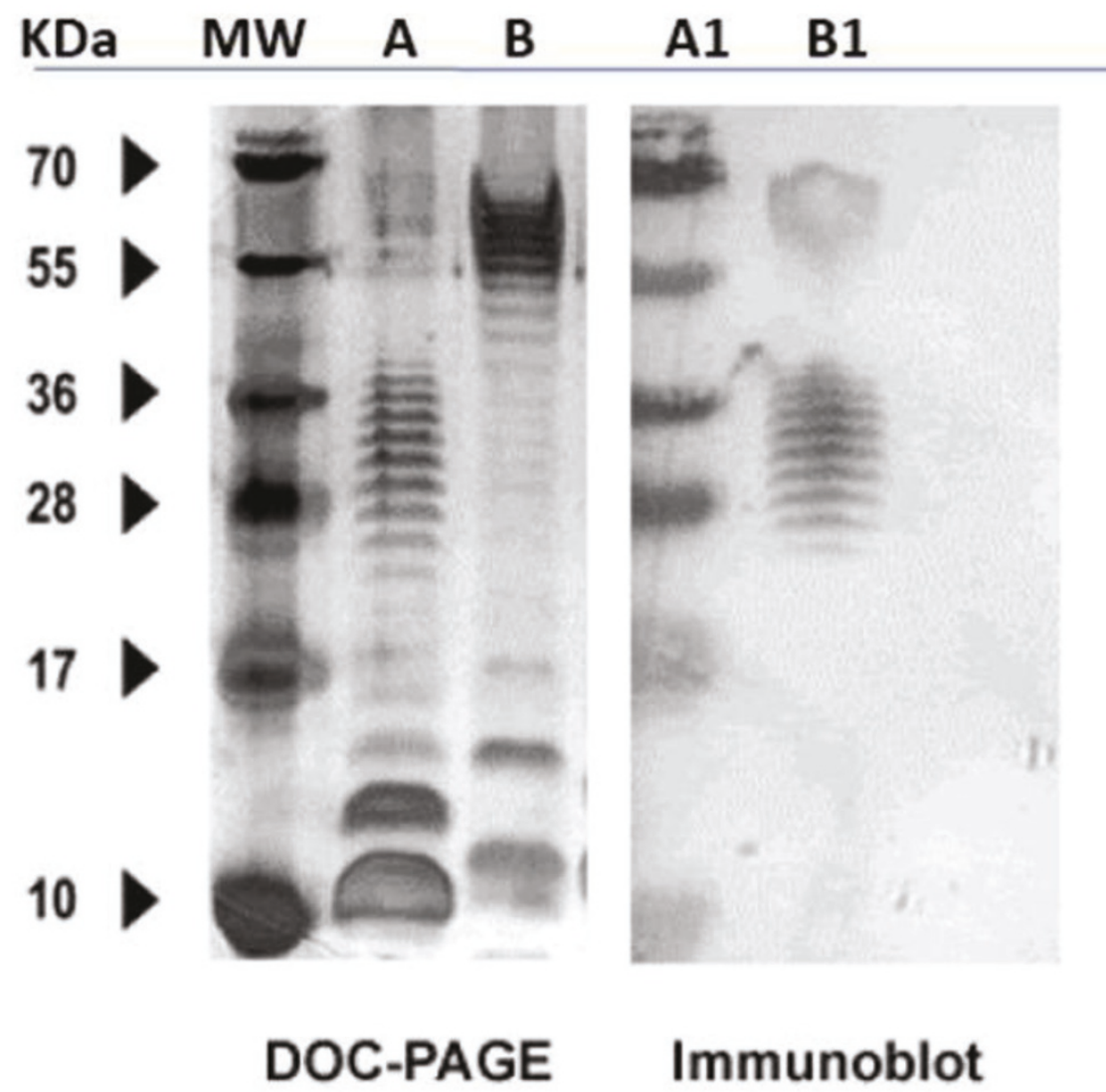

Figure 1 DOC-PAGE (left panel) and immunoblotting (right panel) for LPS extracted from C. muytjensii ATCC 51329 (lanes A and A1) and $E$. coli (lanes B and B1). Blots were probed with mouse antisera collected after immunization with LPS preparation from C. muytjensii ATCC 51329. 
In addition to ELISA, the antigenic specificity of all purified MAbs was tested against OMPs extracted from 12 Cronobacter and 6 non -Cronobacter strains by SDSPAGE followed by immunoblotting.

SDS-PAGE profiles of both Cronobacter and non-Cronobacter revealed the presence of several proteins with molecular weights ranging from 12 to $100 \mathrm{kDa}$ (data not shown) with the majority of OMPs profiles contained 3 to 5 major proteins having molecular weights between 34 and $55 \mathrm{kDa}$. Upon immunoprobing, all MAbs produced similar reaction profile of proteins with molecular weights between 36 to $49 \mathrm{kDa}$ with only one major band for all Cronobacter OMP profiles except isolate Jor44 which did not exhibit any protein (Figure 2, lane 7, C. sakazakii, lower panel). In general, the $36 \mathrm{kDa}$ protein was the most common among all Cronobacter OMP profiles. It was detected by immnunoblotting in 5 out of the 12 tested Cronobacter strains (Figure 2, lower panel; lanes, 5, 6, 9, 10, 11; C. sakazakii, C. turicensis, C. sakazakii, C. sakazakii, C. muytjensii, respectively), and a 42 $\mathrm{kDa}$ protein was detected in two C. sakazakii isolates (Figure 2, lower panel; lanes, 1 and 12), while a $41 \mathrm{kDa}$ protein was detected in two isolates (C. sakazakii, and C. muytjensii, lower lanes 4 and 8 respectively). In addition, proteins of 37 and $39 \mathrm{kDa}$ were detected each in one $C$. sakazakii isolate (Figure 2, lower panel; lanes 2 and 3 , respectively). OMPs from a number of non-Cronobacter species were also tested for reactivity against the purified MAbs by immunoblotting. Unlike the single band pattern observed in Cronobacter OMP immunoblot profiles, the non-Cronobacter immunoblot profiles exhibited a double-band pattern corresponding to MW of 38 and $41 \mathrm{kDa}$ (Figure 3 lower panel; lanes 3, 4, 6 and 7 representing strains; E. coli, P. aeroginusa,
Salmonella, and $S$. sonnii respectively). In addition, $C$. freundii (Figure 3 lower panel; lane 2) exhibited only one protein corresponding to $40 \mathrm{kDa}$, while the only Gram-positive control strain (L. ivanovii, lane 5) exhibited the same two bands with a higher MW (39 and 42 $\mathrm{kDa}$ ) than those which appeared in samples from the Gram-negative isolates. In order to determine which surface antigen the MAbs were bound to, OMPs and LPS extracted from Cronobacter muytjensii ATCC 51329 (strain used for immunization) were analyzed by SDS-PAGE, DOC-PAGE and immunoblotting. All MAbs (A1, B5, 2C2, C5 and A4) displayed strong and specific reaction against a $44 \mathrm{kDa}$ OMP (Figure 4). Although these MAbs were produced from two different fusion experiments, they all reacted strongly and specifically against the same $44 \mathrm{kDa}$ OMP. Furthermore, to compare the epitope specificity of all MAbs, additive index ELISA was conducted for each pair of the MAbs. All scores obtained were very low and fall in the range of 0 to 10 indicating that all MAbs were raised against the same epitope within the $44 \mathrm{kDa} \mathrm{OMP}$.

\section{Protein identification by MALDI-TOF peptide sequencing}

Representatives of the immunoblot-positive proteins were subjected to peptide sequencing and identification using MALDI-TOF Mass spectrometer. Table 2 shows the identified proteins by MALDI-TOF. The $44 \mathrm{kDa}$ protein that was recognized by all the monoclonal antibodies in C. sakazakii appeared to be a novel protein that did not match with any identified protein thus was termed a hypothetical protein.

In addition, the $35 \mathrm{kDa}$ protein identified in the Cronobacter isolate $146_{\mathrm{A}}$ also appeared to be a novel protein termed a hypothetical protein that did not match

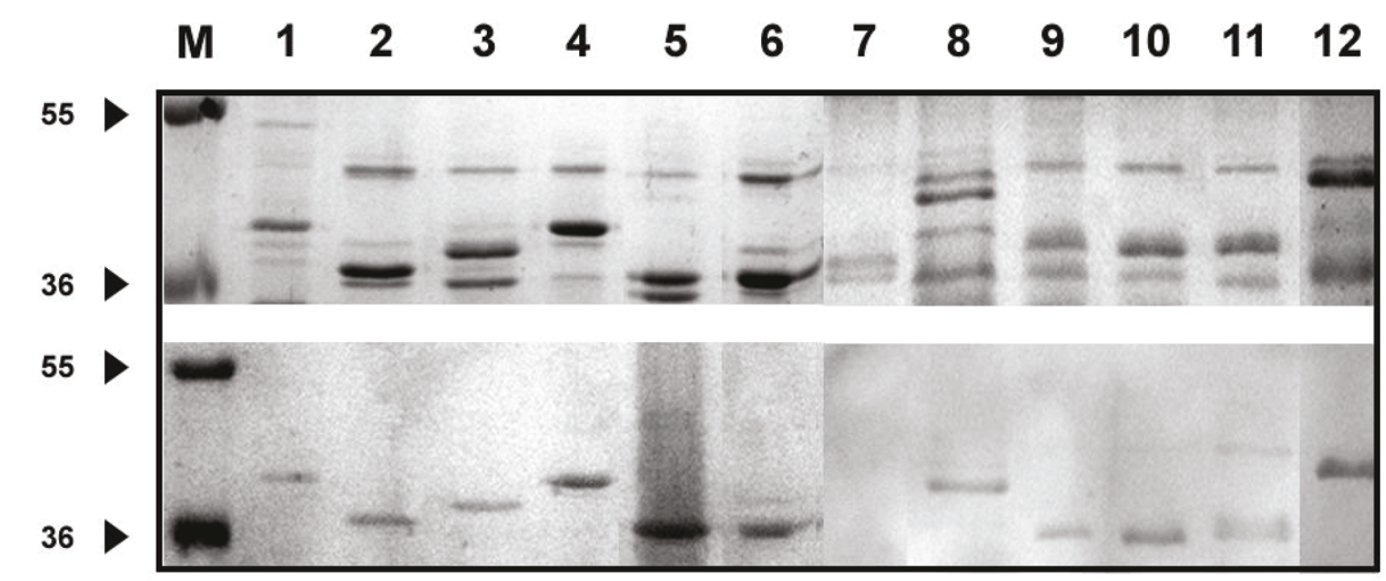

Figure 2 SDS-PAGE (Upper) and Immunoblot (Lower) of OMPs extracted from different Cronobacter strains probed with MAb 2C2. M: Molecular weight marker; 1: C. muytjensii ATCC 51329; 2: C4; 3: C6; 4: C13; 5: Jor93; 6: Jor170; 7: Jor44; 8: Jor112; 9: Jor146A; 10: Jor146 ${ }_{B}$; 11: Jor149; 12: Jor160 


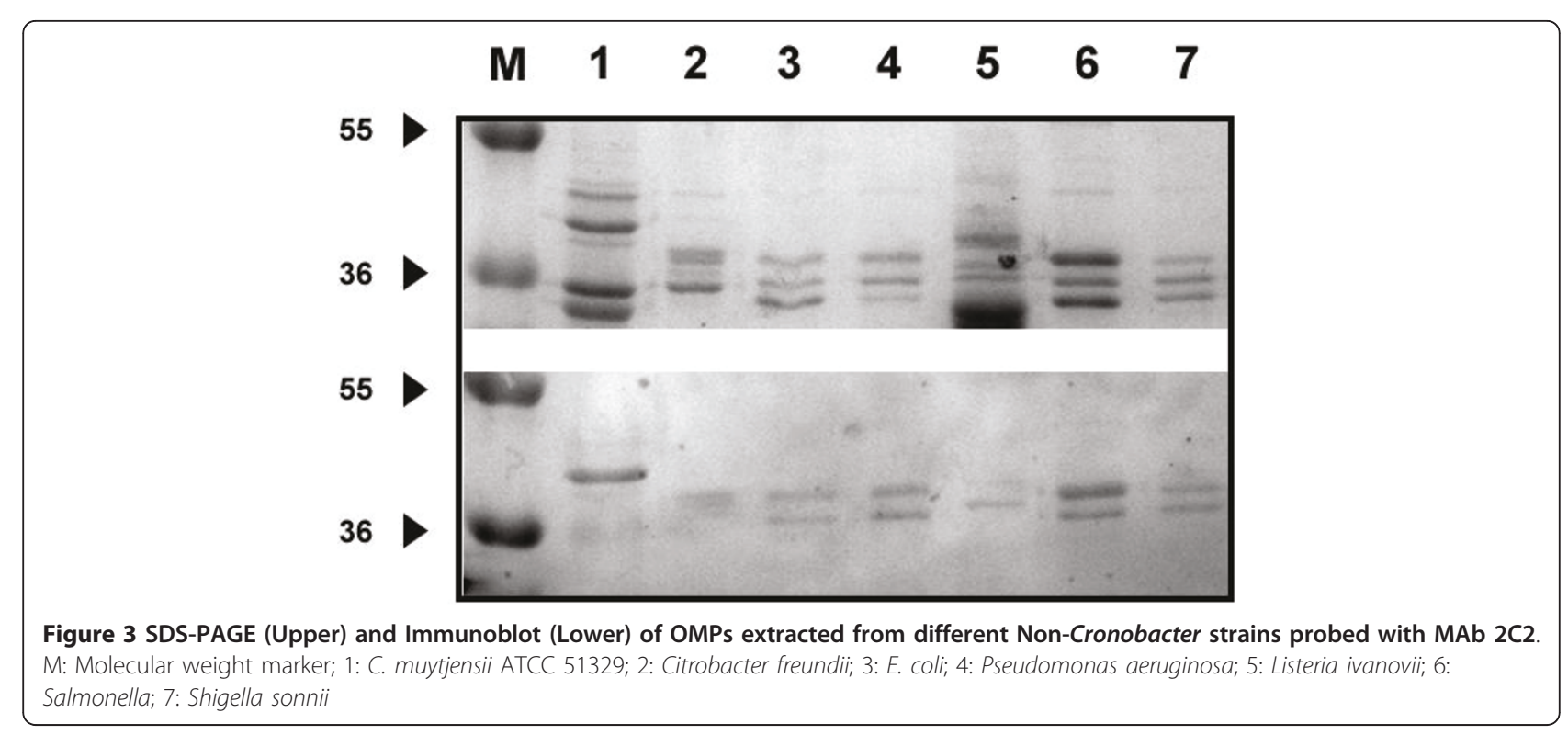

with any known protein sequence deposited in the protein sequence bank (Table 2). Two Cronobacter isolates $\left(160_{\mathrm{A}}\right.$ and $\left.\mathrm{C} 13\right)$ exhibited a $42 \mathrm{kDa}$ protein with identity as a flagellar hook protein FlgE and an outer membrane porin protein in the two isolates respectively. Further, a $40 \mathrm{kDa}$ protein was recognized in Cronobacter isolate 112 , and appeared to be an outer membrane protein $\mathrm{F}$ which is similar to an outer membrane protein $\mathrm{F}$ in $E$. coli. Both E. coli and Salmonella contained another similar protein with a MW of $38 \mathrm{kDa}$ and was identified as an outer membrane protein $\mathrm{A}$. In addition, both exhibited a $35 \mathrm{kDa}$ porin protein yet appeared to be somewhat different.

\section{Effect of different treatments of antigens on MAbs binding affinity}

To gain insights about the nature of the binding between the MAbs and their target epitopes, ELISA and Dot-blot were carried out using different antigens
(OMPs, heat killed bacterial cells, LPS) which were subjected to different treatments (acid, alkaline, denaturing agents and heat) (Figure 5). Acid and base-treatments of whole cell antigens resulted in an increase in the binding affinity between the MAbs and those antigens. These results were confirmed by immunoelectron microscopy. Cronobacter muytjensii ATCC 51329 cells displayed intense colloidal gold labeling after reaction with MAb 2C2 (similar results were obtained with the other MAbs) (Figure 6).

Finally, to determine whether the MAbs recognized sequential (Linear) or conformational epitopes, OMPs were either left intact or denatured by $1 \%(\mathrm{w} / \mathrm{v})$ SDS and boiled for $5 \mathrm{~min}$ and then used as antigens for ELISA. The magnitude of binding of MAbs to antigens was higher for untreated OMPs than the denatured proteins (Table 3). This indicates that, the epitope is conformational and loses its recognition sites once denatured.

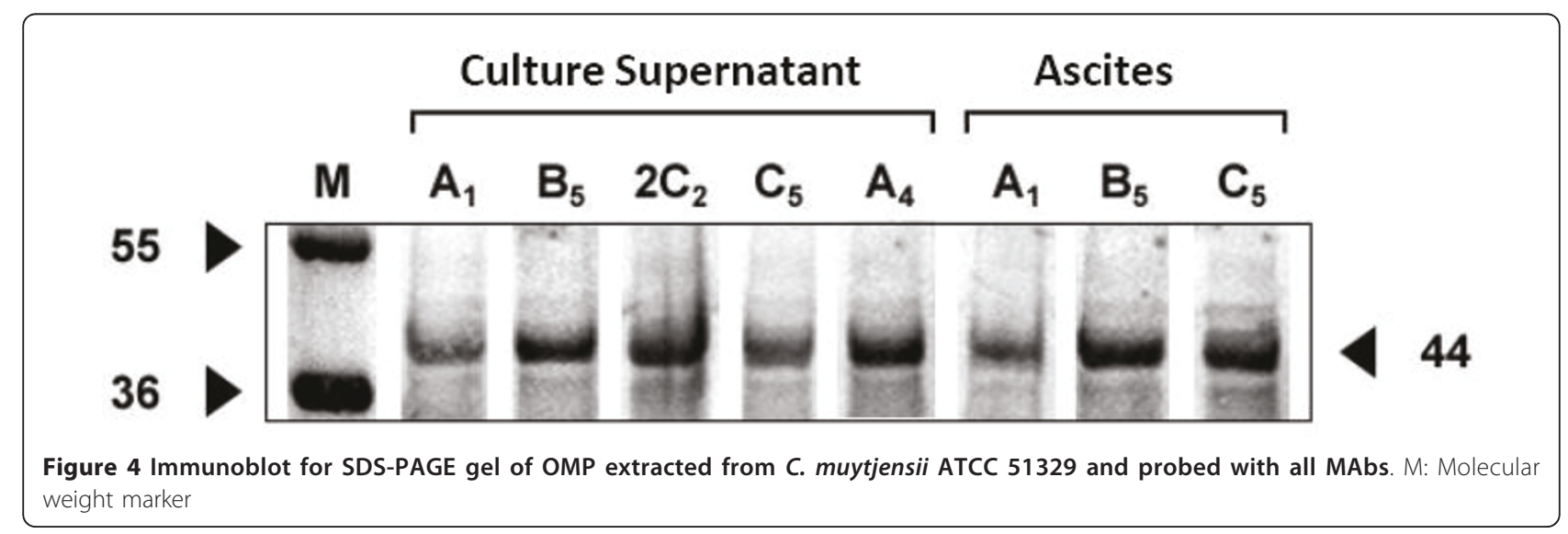


Table 2 Protein bands identified by MALDI-TOF mass spectrometer

\begin{tabular}{|c|c|c|c|c|c|}
\hline Band & Strain & $\begin{array}{l}\text { Predicted MW } \\
(\mathrm{kDa})\end{array}$ & Protein annotation (NCBI database) & $\begin{array}{l}\text { Accession } \\
\text { No. }\end{array}$ & $\begin{array}{l}\text { No. of peptides identified } \\
\text { by MS/MS }\end{array}$ \\
\hline 1 & $160_{A}($ C. sakazakii) & 42 & Flagellar hook protein FlgE [Shigella sonnei Ss046] & gi|74311638 & 1 \\
\hline 2 & Escherichia coli & 35 & Outer membrane protein (porin) [Escherichia coli B171] & gi|75211632 & 5 \\
\hline 3 & Escherichia coli & 38 & Outer membrane protein A [Escherichia coli 536] & gi|110641146 & 7 \\
\hline 4 & Salmonella CIP & 35 & $\begin{array}{l}\text { Outer membrane protein (porin) nmpc precursor } \\
\text { [Escherichia coli CFT073] }\end{array}$ & gi|26247429 & 6 \\
\hline 5 & Salmonella CIP & 38 & Outer membrane protein A [Escherichia coli 536] & gi|110641146 & 8 \\
\hline 6 & C13(C. sakazakii) & 42 & $\begin{array}{l}\text { P COG3203: Outer membrane protein (porin)[Escherichia } \\
\text { coli 101-1] }\end{array}$ & gi|83587007 & 1 \\
\hline 7 & 112 (C. muytjensii) & 40 & Outer membrane protein F [Escherichia coli SMS-3-5] & gi|170682361 & 1 \\
\hline 8 & $146_{\mathrm{A}}($ C. sakazakii) & 35 & $\begin{array}{l}\text { Hypothetical protein ESA_02413 [Enterobacter sakazakii } \\
\text { ATCC BAA-894] }\end{array}$ & gi|156934579 & 8 \\
\hline 9 & $\begin{array}{l}\text { C. muytjensii ATCC } \\
51329\end{array}$ & 44 & $\begin{array}{l}\text { Hypothetical protein ESA_03699 [Enterobacter sakazakii } \\
\text { ATCC BAA-894] }\end{array}$ & gi|156935823 & 3 \\
\hline
\end{tabular}

\section{Discussion}

Antibodies against surface antigens of pathogens aid not only in characterization but also in their classification [35]. In this study monoclonal antibodies were produced against outer membrane proteins of Cronobacter muytjensii. However, we were unable to produce antibodies against LPS. Inability to produce stable hybridomas against LPS could be attributed to the simplicity of the LPS structure which is a linear unbranched chain of repeating polysaccharide units as reported by MacLean et al., [7]. The linearity of the structure was probably responsible for the inability to elicit a significant immune response which was reflected on the inability to produce monoclonal antibodies against LPS of this strain. Luk and Lindberg [36] initially failed to produce stable antibody-producing hybridomas against LPS of Salmonella. Later, they succeeded when they used whole bacterial cells coated with LPS as immunogen. Similarly, Jongh-Leuvenink et al., [37] and Jaradat and Zawistowski [23] were able to produce monoclonal antibodies against LPS of Salmonella. This could be due to differences in the nature of the structure and composition of LPS between Salmonella and Cronobacter spp. and even among different Salmonella serovars.

In this study, the anti-OMP antibodies were characterized for specificity and all 5 monoclonal antibodies not only reacted with Cronobacter species, but also recognized other Enterobacteriaceae. The low specificity indicates that the major outer membrane proteins in the family Enterobacteriaceae are perhaps well conserved as indicated by their antigenic cross-reactivity. The specificity of the monoclonal antibodies was further tested using SDS-PAGE and immunoblotting. The SDSPAGE protein profiles for the OMPs observed in this study were similar to those of OMPs described by other researchers for other members of the Enterobacteriaceae $[38,39]$. Overall, most of the isolates contained OMP proteins with MW ranged from 34-55 kDa (Figure 2 upper panel) with majority of the isolates exhibiting proteins in the range of $36-49 \mathrm{kDa}$ with the $49 \mathrm{kDa}$ protein appeared in all Cronobacter species (Figure 2 upper panel). In contrast, the non-Cronobacter isolates (Figure 3) showed slightly different protein profiles among the Enterobacteriaceae members and even a slight shift in the tested Gram-positive strain, L. ivanovii. The cross-reactivity observed among all Cronobacter strains used in this study indicated that some of these OMPs share common and highly antigenic epitopes. These patterns of cross-reactivity of MAbs with OMPs from bacterial strains within the same species are commonly reported especially for members of the Enterobacteriaceae [38-42]. On the other hand, fewer studies have reported the production of anti-OMP MAbs within species that were non-cross reacting and exhibiting a high degree of specificity $[43,44]$. The reactivity of MAbs to OMP and the lack of any reactivity against LPS indicated that Cronobacter OMPs appeared to be more antigenic than their LPS. This observation coincides with several other reports in which it was demonstrated that OMPS were stronger immunogenes than LPS, and were responsible for producing antibodies with higher affinities [45,46].

All MAbs tested by immunoblotting against OMPs extracted from C. muytjensii ATTC 51329 were able to recognize a $44 \mathrm{kDa}$ protein. This protein appears to contain a highly antigenic epitope capable of eliciting strong immune response in mice against the Cronobacter strain used in the immunization procedure. The identity of this protein was determined by MALDI-TOF MS to be a hypothetical outer membrane protein ESA_03699 [Enterobacter sakazakii ATCC BAA-894]. This protein appeared to be dominant in this particular strain and protruding to the surface making it highly accessible to the host immune system. The specific function of this 


\section{No. of cells spotted}

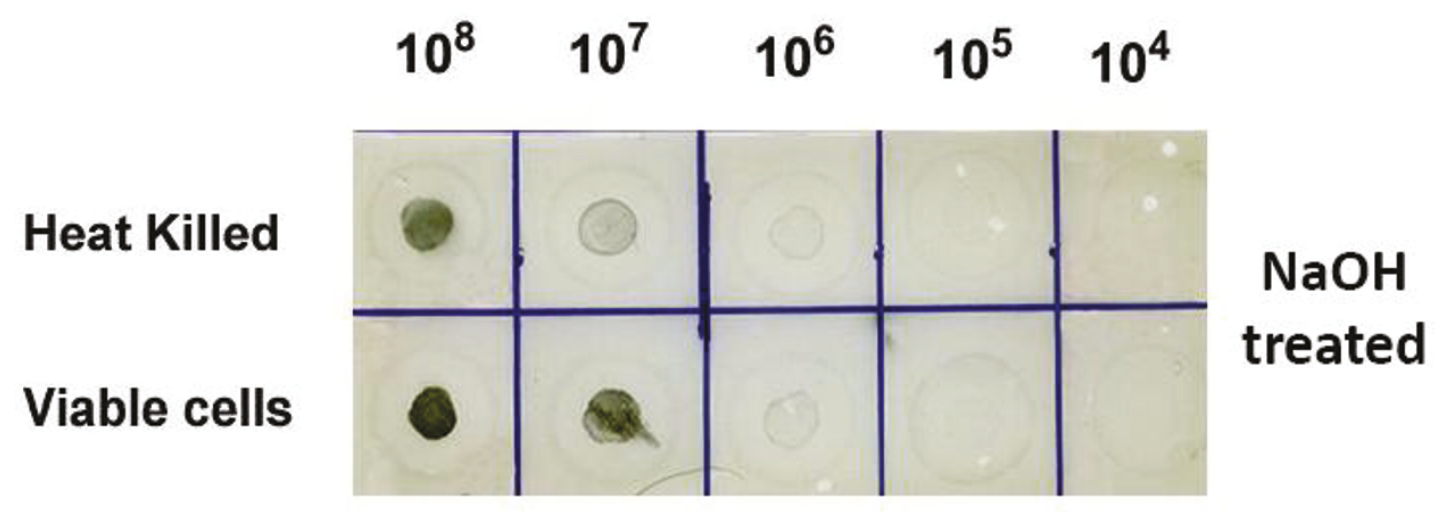

Heat Killed

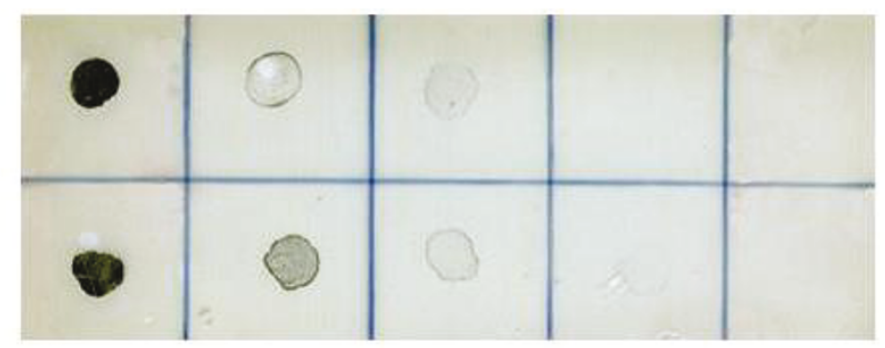

\section{$\mathrm{HCl}$ treated}

Viable cells

\section{Heat Killed}

Viable cells

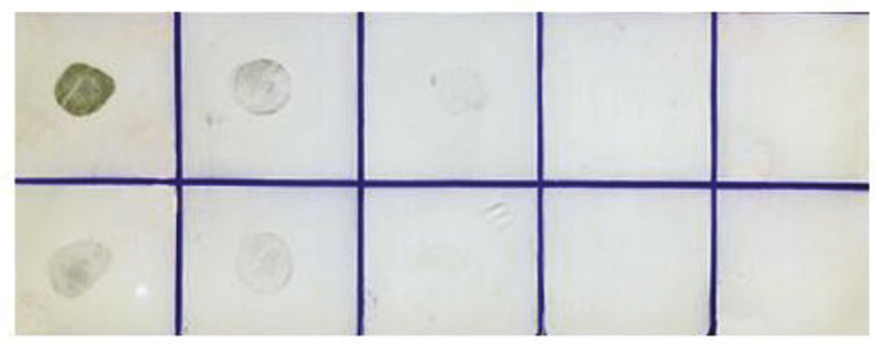

\section{Untreated}

Figure 5 Dot blot assay of whole cells of C. muytjensii ATCC 51329 at different concentrations of live or heat-killed. Upper panel, cells treated with $5 \% \mathrm{NaOH}$ for $10 \mathrm{~s}$, middle panel cells were treated with $38 \% \mathrm{HCl}$ for $10 \mathrm{~s}$ and lower panel, cells were left untreated. All blots were probed with MAb 2 C2.

protein is unknown but it would be of significant interest in future studies since it was not detected in other strains. Other proteins from Cronobacter and non-Cronobacter (E. coli and Salmonella) recognized by the MAbs were also sequenced and aligned against known protein sequences deposited in protein sequence banks. It appeared that most of these proteins are related in terms of their structure and probably function as most of them were outer membrane proteins. However, a $42 \mathrm{kDa}$ protein that was identified in two different Cronobacter spp. appeared to be different both in structure and function as one appeared to be a flagellar protein (Cronobacter $160_{\mathrm{A}}$ ), while the second was identified as an outer membrane protein (Cronobacter C13). Further, as shown in
Table 2 some of the proteins with the same MW (e.g 35 $\mathrm{kDa}$ ) were identified in three different bacteria and each appeared to have a different peptide sequence and consequently different function yet share epitope similarity as they were all recognized by the same MAb indicating a similar function too. Interestingly, similar to the $44 \mathrm{kDa}$ protein, the $35 \mathrm{kDa}$ protein identified in Cronobacter isolate number $146_{\mathrm{A}}$ appeared as novel protein and was termed as a hypothetical protein ESA_02413 with unknown function. Further, a protein of $40 \mathrm{kDa} M W$ was identified in Cronobacter isolate number 112 as an outer membrane protein $\mathrm{F}$ which is similar to a protein in other $E$. coli as revealed from the protein bank sequence (Table 2). 

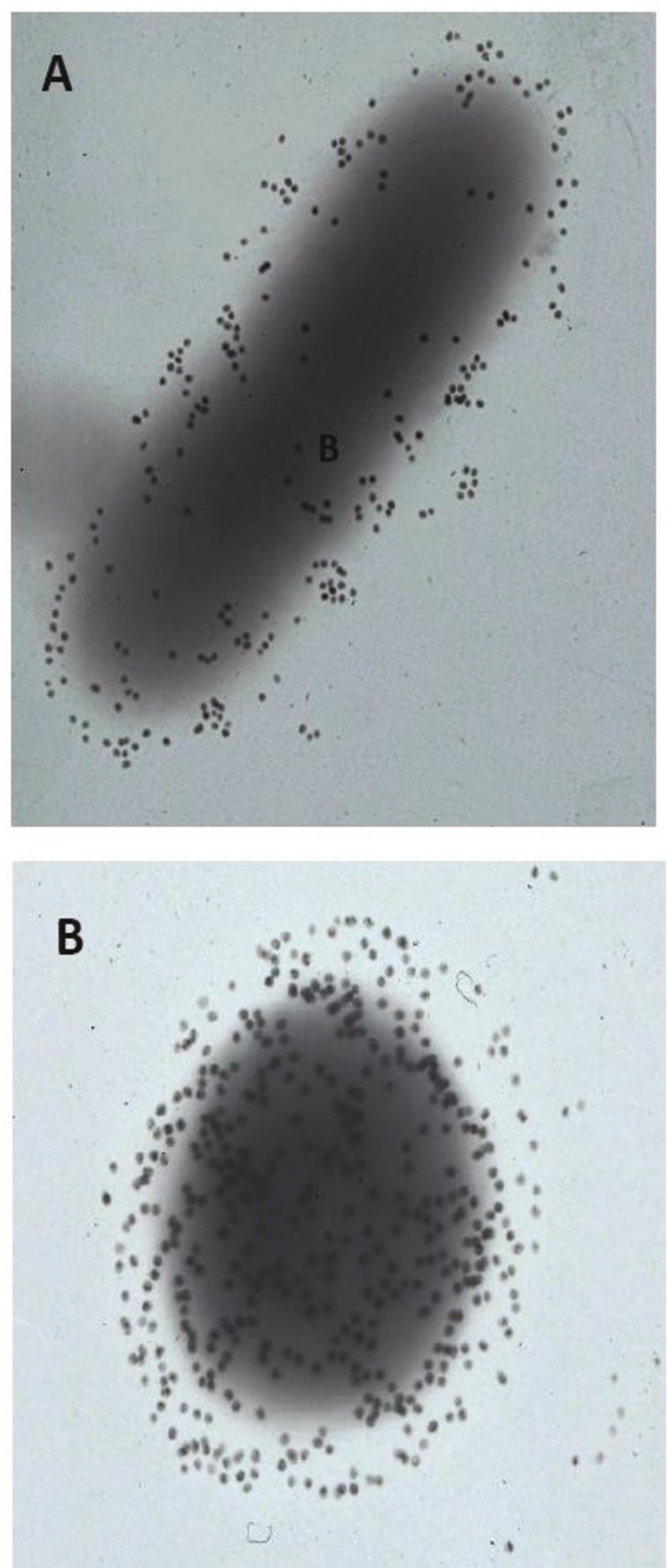

Figure 6 Transmission electron micrographs of C. muytjensii ATCC 51329 treated with $0.1 \mathrm{~N} \mathrm{NaOH} \mathrm{A}$, or $0.1 \mathrm{~N} \mathrm{HCl} \mathrm{B} \mathrm{and} \mathrm{probed} \mathrm{with}$ MAb 2C2 followed by goat anti-mouse Ig conjugated to $18 \mathrm{~nm}$ gold spheres. Magnification $\times 50,000$. 
Table 3 Reactivity of MAbs with different types of treated and untreated antigens as assessed by ELISA

\begin{tabular}{|c|c|c|c|c|c|}
\hline \multirow[t]{2}{*}{ Type of antigen $* *$} & \multirow[t]{2}{*}{ Treatment } & \multicolumn{4}{|c|}{ Absorbance $(405 \mathrm{~nm}) \pm S D *$} \\
\hline & & $\mathrm{A} 1$ & B5 & $2 \mathrm{C} 2$ & C5 \\
\hline$\overline{\mathrm{OMP}}$ & None & $1.375 \pm 0.20$ & $0.720 \pm 0.15$ & $1.234 \pm 0.58$ & $1.481 \pm 0.12$ \\
\hline OMP & $1 \%$ SDS + Boiling for $5 \mathrm{~min}$ & $0.958 \pm 0.07$ & $0.492 \pm 0.04$ & $0.562 \pm 0.08$ & $0.901 \pm 0.08$ \\
\hline WC & None & $1.365 \pm 0.08$ & $0.565 \pm 0.07$ & $0.725 \pm 0.08$ & $0.835 \pm 0.03$ \\
\hline WC & Heat & $1.156 \pm 0.16$ & $0.423 \pm 0.08$ & $0.782 \pm 0.03$ & $1.026 \pm 0.19$ \\
\hline LPS & None & $0.553 \pm 0.08$ & $0.454 \pm 0.04$ & $0.425 \pm 0.09$ & $0.531 \pm 0.04$ \\
\hline None & None & $0.477 \pm 0.05$ & $0.469 \pm 0.24$ & $0.520 \pm 0.07$ & $0.412 \pm 0.17$ \\
\hline
\end{tabular}

OMP: outer membrane protein; WC: whole cell; LPS: Lipopolysaccharides, SD: Standard deviation.

* Absorbance represents the average of two readings.

** All antigens were prepared from C. muytjensii ATCC 51329.

The findings in the current study provide an evidence of great similarity among Cronobacter spp. and the other members of Enterobacteriaceae. Such findings were comparable to several previous studies which reported similar cross reactivity among major OMPs in Gram negative bacteria and among members of the Enterobacteriaceae [38-42]. For example, monoclonal antibodies that recognized buried epitopes of the ompC from Salmonella typhi were shown to cross react with porins extracted from 13 species of Enterobacteriaceae [41]. In addition, it appeared that OMPs extracted from Cronobacter and non-Cronobacter spp. in this study shared similar epitopes. This was evident in the multiple proteins which were recognized by the same MAbs that appeared to be specific toward the $44 \mathrm{kDa}$ OMP extracted from the Cronobacter strain used for immunization. Indeed, these results highlighted the heterogeneity of the OMPs in the Cronobacter isolates.

The effect of acid or base treatment on the reactivity of monoclonal antibodies to their antigens was investigated. Acid or base treatment increased binding affinity of the antibodies to Cronobacter cells. This might be due to an increase in the accessibility of MAbs to the surface protein antigens due to removal of some extracellular molecules and/or LPS that might have hindered the binding of MAbs to their target proteins in the case of whole bacterial cells. For example, LPS accounts for up to $70 \%$ of the outer monolayer [47]. Indeed, the masking effect of LPS against binding of antibodies to antigens has been reported and therefore it can not be under estimated [48]. These observations were further confirmed by immunoelectron transmission microscopy (Figure 6). When live untreated Cronobacter cells were probed with $\mathrm{MAb} 2 \mathrm{C} 2$, there was no binding to the primary antibodies and hence no gold particle labeling. However, when Cronobacter cells were treated with $\mathrm{NaOH}$ (Figure 6A) or $\mathrm{HCl}$ (Figure 6b), the antibodies appeared to have gained access to their target represented by increased labeling. In addition, the MAbs were shown to be bound more strongly to conformational rather than sequential (linear) epitopes highlighting the specificity of the MAbs to their epitopes as appeared in Table 3[41].

\section{Conclusions}

To our knowledge, this is the first study that describes the production of monoclonal antibodies against whole cells of $C$. muytjensii with concomitant identification of the recognized proteins by MALDI-TOF spectrometry. All MAbs produced in this study were reactive against the whole cell antigen and Cronobacter OMPs. MAbs reacted with OMPs of molecular weight ranging between 36 and $49 \mathrm{kDa}$. However, none of the MAbs showed any reaction with LPS extracted from Cronobacter. All MAbs recognized conformational epitopes rather than sequential as it is evident from the decrease in their binding affinity to fully denatured OMP antigens. Moreover, all MAbs exhibited a high cross-reactivity against the whole cell antigen and OMPs from non-Cronobacter. As apparent from the MALDI-TOF protein identification, the overall results indicated that, the major OMPs found in the Enterobacteriaceae are sufficiently conserved thereby, promoting antigenic cross-reactivity between genera. Furthermore, the single-banding pattern and the high titers obtained in immunoblotting and ELISA for the Cronobacter strains indicated that the OMPs of closely related strains are more conserved compared with other genera evaluated. The results from this study can be of great help for possible vaccine production against this pathogen in infants and young children.

\section{Acknowledgements}

The authors would like to acknowledge the Deanship of Research at Jordan University of Science and Technology for funding this research project (project number 85/2008). In addition, the authors extend their deep gratitude for Professor Greg Blank, from the University of Manitoba, for his critical review of the manuscript and Hyochin Kim from Purdue University for assistance with MALDI-TOF analysis of proteins, and Muneer Khdor, from Yarmouk University, for his assistance with Electron microscopy.

\section{Author details}

'Department of Biotechnology and Genetic Engineering, P. O Box 3030, Jordan University of Science and Technology, Irbid 22110, Jordan. 
2Department of Biochemistry and Biophysics, Texas A \& M University, College Station, Texas 77843-2128, USA. ${ }^{3}$ Princes Haya Biotechnology Center, Jordan University of Science and Technology, Irbid, 22110, Jordan. ${ }^{4}$ Department of Food Science, Purdue University, West Lafayette, Indiana, 47907, USA

\section{Authors' contributions}

ZJ secured the funding for the project, analyzed data and wrote the final manuscript, $A R$ and QA conducted the experimental work and participated in drafting the initial manuscript, $S$ J helped in the experimental work and $A B$ edited the manuscript and participated in data analysis. All authors have read and approved the final manuscript.

\section{Competing interests}

The authors declare that they have no competing interests.

Received: 4 April 2011 Accepted: 25 June 2011 Published: 25 June 2011

\section{References}

1. Gallagher PG: Enterobacter bacteremia in pediatric patients. Rev Infect Dis 1990, 12:808-812.

2. Nazarowec-White M, Farber JM: Phenotypic and genotypic typing of food and clinical isolates of Enterobacter sakazakii. J Med Microbiol 1999, 48:559-567.

3. Farmer JJ, Asbury MA, Hickman FW, Brenner DJ: The Enterobacteriaceae Study Group; Enterobacter sakazakii, new species of Enterobacteriaceae isolated from clinical specimens. Int J Sys Bacteriol 1980, 30:569-584.

4. Iversen C, Waddington M, Farmer JJ, Forsythe SJ: The biochemical differentiation of Enterobacter sakazakii genotypes. BMC Microbiol 2006, 6:94.

5. Iversen C, Lehner A, Mullane N, Bidlas E, Cleenwerck I, Marugg J, Fanning S, Stephan $\mathrm{R}$, Joosten $\mathrm{H}$ : The taxonomy of Enterobacter sakazakii: proposal of a new genus Cronobacter gen. nov. and descriptions of Cronobacter sakazakii comb. no. Cronobacter sakazakii subsp. sakazakii, comb.nov., Cronobacter sakazakii subsp. Malonaticus subsp. Nov., Cronobacter dublinensis sp. Nov. and Cronobacter genomospecies I. BMC Evolut Biol 2007, 7:46.

6. Iversen C, Mullane M, McCardell B, Tall BD, Lehner A, Fanning S, Stephan R, Joosten H: Cronobacter gen. nov., a new genus to accommodate the biogroups of Enterobacter sakazakii, and proposal of Cronobacter sakazakii gen. nov., comb. nov., C. malonaticus sp. nov., C. turicensis, sp. nov., C. muytjensii sp. nov., C. dublinensis sp. nov., Cronobacter genomospecies I, and of three subspecies. C. dublinensis sp. nov. subsp. dublinensis subsp. nov. C. dublinensis sp. nov. subsp. lausannensis subsp. nov., and C. dublinensis sp. nov. subsp. lactaridi subsp. Nov. Int I Sys Evol Microbiol 2008, 58:1442-1447.

7. MacLean LL, Pagotto F, Farber JM, Perry MB: The structure of the Oantigen in the endotoxin of the emerging food pathogen Cronobacter (Enterobacter) muytjensii strain 3270. Carb Res 2009, 344:667-671.

8. Nair MK, Venkitanarayanan KS: Cloning and sequencing of the ompA gene of Enterobacter sakazakii and development of an ompA-targeted PCR for rapid detection of Enterobacter sakazakii in infant formula. Appl Environ Microbiol 2006, 72:2539-2546.

9. Nair MK, Venkitanarayanan KS, Silbart LK, Kim KS: Outer Membrane Protein A (OmpA) of Cronobacter sakazakii binds fibronectin and contributes to invasion of human brain microvascular endothelial cells. Foodborne Pathog Dis 2009, 6:495-501.

10. Singamsetty VK, Wang $Y$, Shimada $H$, Prasadarao NV: Outer membrane protein A expression in Enterobacter sakazakii is required to induce microtubule condensation in human brain microvascular endothelial cells for invasion. Microb Pathog 2008, 45:181-191.

11. Masi M, Saint N, Molle G, Pagès JM: The Enterobacter aerogenes outer membrane efflux proteins TolC and EefC have different channel properties. Biochim biophys Acta 2007, 1768:2559-2567.

12. de Kort $G$, van der Bent-Klootwijk P, van de Klundert JA: Immuno-detection of the virulence determinant $\mathrm{OmpX}$ at the cell surface of Enterobacter cloacae. FEMS Microbiol Lett 1998, 158:115-20.

13. de Kort G, Bolton A, Martin G, Stephen J, van de Klundert JA: Invasion of rabbit ileal tissue by Enterobacter cloacae varies with the concentration of OmpX in the outer membrane. Infect Immun 1994, 62:4722-4726.
14. Agostoni C, Axeisson I, Goulet O, Koletzko B, Michaelsen FK, Puntis WL, Rigo J, Shamir R, Szajewska H, Turck D, Vandenplas Y, Weaver LT: Preparation and Handling of Powdered Infant Formula: A Commentary by the ESPGHAN Committee on Nutrition. J Pediat Gastroenterol Nut 2004, 39:320-322.

15. Bown $A B$, Braden $C R$ : Invasive Enterobacter sakazakii Disease in Infants. Emerg Infect Dis 2006, 12:1185-1189.

16. Drudy D, Mullane NR, Quinn T, Wall PG, Fanning S: Enterobacter sakazakii: An emerging pathogen in powdered infant formula. Food Safety 2006, 42:996-1002

17. Kothary MH, McCardell BA, Frazar CD, Deer D, Tall BD: Characterization of the zinc-containing metalloprotease $(\mathrm{zpx})$ and development of a species-specific detection method for Enterobacter sakazakii. Appl Environ Microbiol 2007, 73:4142-4151.

18. Chap J, Jackson P, Siqueria R, Gasper N, Quintas C, Park J, Osaili T, Shaker R, Jaradat Z, Hartantyo SHP, Abdullah Sani N, Estuningsih S, Forsythe SJ: International survey of Cronobacter sakazakii and other Cronobacter spp. in follow up formulas and infant foods. Int J Food Microbiol 2009, 136:185-188.

19. Jaradat ZW, Ababneh QO, Saadoun IM, Samara NA, Rashdan MA: Isolation of Cronobacter spp. (formerly Enterobacter sakazakii) from infant food, herbs and environmental samples and the subsequent identification and confirmation of the isolates using biochemical, chromogenic assays, PCR and 16S rRNA sequencing. BMC Microbiol 2009, 9:225.

20. Molloy M, Cagney C, O'Brien S, Iversen C, Fanning S, Duffy G: Surveillance and characterization by pulse-field gel electrophoresis of Cronobacter spp. in farming and domestic environments, food production animals and retail foods. Int J Food Microbiol 2009, 136:198-203.

21. Lai KK: Enterobacter sakazakii infections among neonates, infants, children and adults. Medicine 2001, 80:113-122.

22. Gurtler JB, Kornacki JL, Beuchat LR: Enterobacter sakazakii A coliform of increased concern to infant health. Int J Food Microbiol 2005, 104:1-34.

23. Jaradat Z, Zawistowski J: Production and characterization of monoclonal antibodies against the $\mathrm{O5}$ antigen of Salmonella typhimurium lipopolysaccharide. Appl Environl Microbiol 1996, 62:1-5.

24. Pupo E, Aguila A, Santana H, Nunez J, Castellanos-Serra L, Hardy E: Mice immunization with gel electrophoresis-micropurified bacterial lipopolysaccharides. Electrophoresis 1999, 20:458-461.

25. Banada PP, Bhunia AK: Antibodies and immunoassays for detection of bacterial pathogens. In Principles of Bacterial Detection: Biosensors, Recognition Receptors and Microsystems. Volume Chapter 21. Edited by: Zourob M, Elwary S, Turner A. Springer, New York; 2008:567-602.

26. Davies RL, Wall RA, Borriello SP: Comparison of methods for the analysis of outer membrane antigens of Neisseria meningitis by western blotting. J Immunol Methods 1990, 134:215-25.

27. Liddell JE, Cryer A: A practical guide to monoclonal antibodies. John Wiley and Sons, Chichester, UK; 1991.

28. Harlow ED, Lane D: Antibodies; A laboratory manual. Cold Spring Harbor, USA; 1988

29. Friguet $B$, Djavadi-Chaniance $L$, Golberg M: A convenient enzyme linked immunosorbent assay for testing whether monoclonal antibodies recognize the same antigenic site. Immunoenzymatic techniques Academic Press, London; 1983, 171-17.

30. Laemmli UK: Cleavage of structural proteins during the assembly of the head of bacteriophage T4. Nature 1970, 227:680-685.

31. Reuhs BL, Geller DB, Kim JS, Fox JE, Kolli VSK, Pueppke SG: Sinorhizobium fredii and Sinorhizobium meliloti produce structurally conserved lipopolysaccharides and strain-specific K antigens. Appl Environ Microbiol 1998, 64:4930-4938.

32. Padhye W, Zhao T, Doyle MP: Production and characterization of monoclonal antibodies to Verotoxins 1 and 2 from Escherichia coli of serotype O 157:H7. J Med Microbiol 1989, 30:219-226.

33. Pettersson A, Kuipers $B$, Pelzer $M$, Verhagen $E_{1}$ Tiesjema RH, Tommassen J, Poolman J T: Monoclonal antibodies against the 70-kilodalton ironregulated protein of Neisseria meningitis are bactericidal and strain specific. Infect Immun 1990, 58:3036-3041.

34. Tadjine M, Mittal KR, Bourdon S, Gottschalk M: Production and characterization of murine monoclonal antibodies against Haemophilus parasuis and study of their protective role in mice. Microbiology 2004, 150:3935-3945. 
35. Brooks BW, Lutze-Wallace CL, Maclean LL, Vinogradov E, Perry MB: Identification and differentiation of Taylorella equigenitalis and Taylorella asinigenitalis by lipopolysaccharide O-antigen serology using monoclonal antibodies. Can J Vet Res 2010, 74:18-24.

36. Luk JM, Lindberg AA: Rapid and sensitive detection of Salmonella $(0: 6,7)$ by immunomagnetic monoclonal antibody-based assays. J Immunol Methods 1991, 137:1-8.

37. Jongh-Leuvenink J, Bouter AS, Marcelis JH, Schelleken J, Verhoef J: Crossreactivity of monoclonal antibodies against lipopolysaccharides of gramnegative bacteria. Euro J Clin Microbio/ 1986, 5:148-151.

38. Hofstra H, Van Tol JD, Dankert J: Cross-reactivity of major outer membrane proteins of Enterobacteriaceae, studied by crossed immunoelectrophoresis. J Bacteriol 1980, 143:328-37.

39. Jaradat ZW, Zawistowski J: Antigenically stable $35 \mathrm{kDa}$ outer membrane protein of Salmonella. Food Agri Immunol 1998, 10:257-270.

40. Henriksen AZ, Maeland JA, Brakstad OG: Monoclonal antibodies against three different enterobacterial outer membrane proteins. Characterization, cross-reactivity, and binding to bacteria. Acta Pathol Microbio Immun Scand 1989, 97:559-568.

41. Singh SP, Upshaw Y, Abdullah T, Singh SR, Klebba PE: Structural relatedness of enteric bacterial porins assessed with monoclonal antibodies to Salmonella typhimurium OmpD and OmpC. J Bacterio/ 1992, 174:1965-1973.

42. Hellman J, Zanzot EM, Loiselle PM, Amato SF, Black KM, Ge Y, Kurnick JT Warren HS: Antiserum against Escherichia coli J5 contains antibodies reactive with outer membrane proteins of heterologous gram-negative bacteria. J Infect Dis 1997, 176:1260-8.

43. Robertson SM, Frisch CF, Gulig PA, Kettman JR, Johnston KH, Hansen EJ: Monoclonal antibodies directed against a cell surface-exposed outer membrane protein of Haemophilus influenzae type b. Infect Immun 1982, 36:80-88.

44. Hamel J, Brodeur BR, Belmaaza A, Montplaisir S, Musser JM, Selander RK: Identification of Haemophilus influenzae type $b$ by a monoclonal antibody coagglutination assay. J Clin Microbiol 1987, 25:2434-2436.

45. Kuusi N, Nurminen M, Saxén H, Mäkelä PH: Immunization with major outer membrane protein (porin) preparations in experimental murine salmonellosis: effect of lipopolysaccharide. Infect Immun 1981, 34:328-332.

46. Isibasi A, Ortiz V, Vargas M, Paniagua J, González C, Moreno J, Kumate J: Protection against Salmonella typhi infection in mice after immunization with outer membrane proteins isolated from Salmonella typhi 9, 12, d, Vi. Infect Immun 1998, 56:2953-2959.

47. Lugtenberg B, Van Alphen L: Molecular architecture and functioning of the outer membrane of Escherichia coli and other gram-negative bacteria. Biochim Biophys Acta 1983, 737:51-115.

48. Cloeckaert A, de Wergifosse P, Dubray G, Limet JN: Identification of seven surface-exposed Brucella outer membrane proteins by use of monoclonal antibodies: immunogold labeling for electron microscopy and enzyme-linked immunosorbent assay. Infect Immun 1990, 58:3980-3987.

doi:10.1186/1471-2180-11-148

Cite this article as: Jaradat et al:: Characterization of surface proteins of Cronobacter muytjensii using monoclonal antibodies and MALDI-TOF Mass spectrometry. BMC Microbiology 2011 11:148.

\section{Submit your next manuscript to BioMed Central and take full advantage of:}

- Convenient online submission

- Thorough peer review

- No space constraints or color figure charges

- Immediate publication on acceptance

- Inclusion in PubMed, CAS, Scopus and Google Scholar

- Research which is freely available for redistribution

Submit your manuscript at www.biomedcentral.com/submit
Biomed Central 